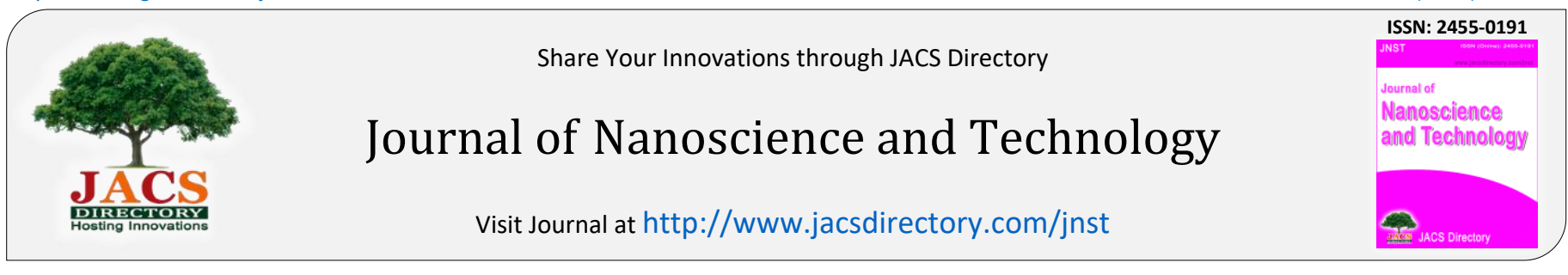

\title{
Biosynthesis and Characterization of Silver Nanoparticles from Tinospora cordifolia Root Extract
}

\author{
Tessy John ${ }^{1, *}$, Kokila A. Parmar², Paras Tak \\ ${ }^{1}$ Department of Physics, Faculty of Science, Pacific University, Udaipur - 313 003, Rajasthan, India. \\ ${ }^{2}$ Department of Chemistry, Faculty of Science, Hemachandracharya North Gujarat University, Patan, Ahmadabad - 384 265, Gujarat, India.
}

\section{ARTICLE DETAILS}

\section{Article history:}

Received 21 February 2019

Accepted 09 March 2019

Available online 20 March 2019

Keywords:

Green Synthesis

Silver Nanoparticles

Antimicrobial Activity

\begin{abstract}
A B S T R A C T
Green synthesis of silver nanoparticles is one of the promising branches of nanotechnology for applications in different biomedical fields. In the present investigation, methanol extract of Tinospora cordifolia root were used as reducing agent. Then the silver nanoparticles are characterized using UVVis, SEM, XRD, TEM and FTIR spectroscopic techniques. The functional biomolecules responsible for the reduction of the silver ions and the capping of the silver nanoparticles by the plant extract Tinospora cordifolia were identified by the Fourier transform infrared spectroscopy (FTIR) analysis. The TEM analysis shows that the silver nanoparticles with an average size of $100 \mathrm{~nm}$. X-ray diffraction analysis showed that the particles were crystalline in nature.
\end{abstract}

\section{Introduction}

In recent years, Silver nanoparticles are receiving great interest due to their diverse applications [1-6]. Green synthesis of silver nanoparticles has become a major focus for researchers due to their simplicity of procedures, nontoxic, stability and eco-friendly [7-8]. The initial step in the synthesis of silver nanoparticles involves reduction of silver ions to neutral atoms with a strong reducing agent. In case of biological synthesis of silver nanoparticles, bio components such as microorganism, plant extract have been found to be excellent sources of natural reducing agents [9-14]. Phytochemicals such as polyphenols and alkaloids etc. have been found to be suitable reducing agents in the synthesis of metal nanoparticles [15-17]. In this study, Tinospora cordifolia plant extract was used as a reducing agent to synthesis silver nanoparticles.

Tinospora cordifolia belonging to the family Menispermaceae is a genetically diverse, large, deciduous climbing shrub with greenish yellow typical flowers, found at higher altitude [18]. It is commonly known as "Guduchi" in Ayurveda [19-21]. It has been used as an important drug by ayurveda practitioners in various diseased conditions. The plant mainly contains biologically active chemical constituents like alkaloids, glycosides, steroids, sesquiterpenoid, aliphatic compound, essential oils, mixture of fatty acids and polysaccharides. The plant possesses medicinal properties like anti-diabetic, anti-periodic, anti-spasmodic, antiinflammatory, anti-arthritic, anti-oxidant, anti-allergic, anti-stress, antileprotic, anti-malarial, hepatoprotective, immunomodulatory and antineoplastic activities [22].
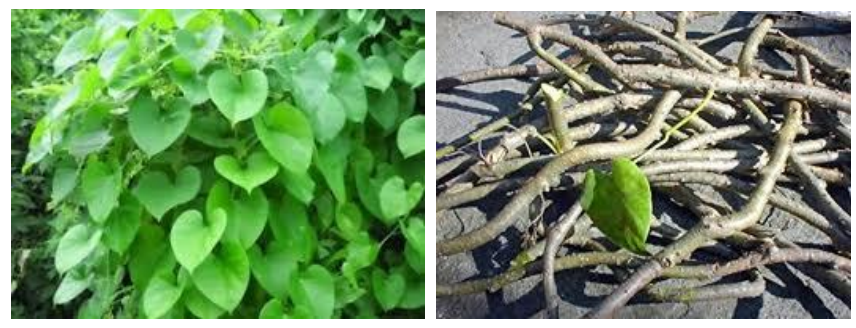

Fig. 1 Tinospora cordifolia a) leaves and b) roots

\section{Experimental Methods}

\subsection{Synthesis of Silver Nanoparticles}

Silver nitrate was purchased from Sigma Aldrich chemicals. All the glassware were cleaned and washed with double distilled water to remove any impurities and dried in an oven before use. Tinospora cordifolia roots were collected and rinsed thoroughly with distilled water and shade dried for 15 days. The roots were finely powdered and used for preparation of the extract. $5 \mathrm{~g}$ of such powder was mixed with $250 \mathrm{~mL}$ of methanol and the mixture was left at room temperature for two days. The extract was filtered through Whatman no.1 filter paper and the filtrate used for silver nanoparticle synthesis. $0.1 \mathrm{M} \mathrm{AgNo3}$ was prepared by dissolving $4.25 \mathrm{~g}$ $\mathrm{AgNo}_{3}$ in $250 \mathrm{~mL}$ double distilled water. $100 \mathrm{~mL}$ of methanol extract of Tinospora cordifolia root was added to $100 \mathrm{~mL}$ of $0.1 \mathrm{M}$ aqueous $\mathrm{AgNo}_{3}$ solution at room temperature for the reduction of silver nanoparticles. The reduction of silver ions takes place within $15 \mathrm{~min}$ at room temperature. Slowly the color started changing from colorless to brown and finally reddish brown, indicating the formation of silver nanoparticles.

\subsection{Characterization of Silver Nanoparticles}

\subsubsection{UV-Vis Studies of Silver Nanoparticles}

The reduction of silver nitrate to pure $\mathrm{Ag}^{+}$ions using methanol extract of Tinospora cordifolia root was monitored by measuring the UV-Vis spectrum of the reaction medium. The sample were diluted with $3 \mathrm{~mL}$ of acetone and measured for UV-Vis spectrum at room temperature in the range $200-800 \mathrm{~nm}$. Acetone was used as reference.

\subsubsection{FTIR Analysis}

FTIR measurement was carried out to identify the biomolecules present in Tinospora cordifolia root extract and the interaction between the nanoparticles were identified by the Fourier transform infrared spectroscopy (FTIR) analysis. FTIR spectra of the purified silver nanoparticles powder were analyzed by FTIR spectroscopy. FTIR results were obtained (Thermo Nicolet, Avatar 370) in the range $4000-400 \mathrm{~cm}^{-1}$. FTIR spectra were measured using the $\mathrm{KBr}$ pellet method. The bioreduced solution was centrifuged at $2500 \mathrm{rpm}$ for 30 minutes at room temperature to remove free constituents present in the solution and the pellet was obtained. The pellet was redispersed in distilled water. The process of centrifugation and re-dispersion in sterile water was repeated thrice. Then the purified silver nanoparticles were dried in oven at $100{ }^{\circ} \mathrm{C}$. The FTIR spectrum of the dried sample was carried out to study the presence of 
reducing groups in the extract responsible for the formation of silver nanoparticles.

\subsubsection{SEM and TEM Analysis of Silver Nanoparticles}

The scanning electron microscope (SEM) has been employed for the morphological characterization of the synthesized silver nanoparticles. It was done using SIGMA model. The size and morphology of the resultant particles were visualized with the help of transmission electron microscopy [TEM] (Jeol/JEM 2100). The samples for TEM were prepared by placing a drop of silver nanoparticles on a copper grid, which were dried before transferring it to the microscope.

\subsubsection{X-Ray Diffraction (XRD Analysis)}

The crystallinity of silver nanoparticles was determined by X-ray diffractometer (Bruker AXS D8 Advance). The average crystalline size of the synthesized silver nanoparticles was calculated using Scherrer's formula,

$$
D=\frac{0.9 \lambda}{\beta \cos \theta}
$$

where $\mathrm{D}$ is the average crystallite domain size perpendicular to the reflecting planes, $\lambda$ is the X-ray wavelength, $\beta$ is the full width at half maximum (FWHM), and $\theta$ is the diffraction angle.

\subsection{Antibacterial Activity of Silver Nanoparticles}

The antibacterial activity performed by antimicrobial susceptibility tests, NCCLS 1993, Approved standard: M2-A5. E. Coli (Gram negative), S. aerious (Gram positive), K. pneumonia (Gram negative) and P. aeruginosa (Gram negative) strains were used for the antibacterial activity. The minimum inhibitory concentration (MIC) of compounds for each test organism was determined by a modification of the broth dilution method performed in 96 well micro-trays (NCCLS, 1993). The data analysis was accomplished using Graph Pad Prism software (Ver. 5.04) (Graph Pad Software, Inc., USA). IC50 values were obtained from regression lines with coefficient factors between $\mathrm{R}^{2}=0.52$ and 0.99 . Absorbance at $595 \mathrm{~nm}$ between reading taken before and after incubation of the plates.

\subsection{In-Vitro Cytotoxicity Analysis.}

The nano-metallic compounds were studied against various cell line named MCF-7 and HEP-2 along with standard anticancer drug i.e. Methotrexate. MCF-7 and HEP-2 cell cultures were used in these experiments were derived from National Centre for Cell Science (NCCS), Pune. Linear regression analysis with $95 \%$ confidence limit and $\mathrm{R}^{2}$ were used to define dose-response curves and to compute the concentration of chemical agents needed to reduce absorbance of the formazan by $50 \%$ (IC50). Dose response curve (DRC) against all cell lines was plotted with 10 analysis point i.e. with 10 different drug concentrations. The concentration causing $50 \%$ cell growth inhibition ( IC $_{50}$ ) was determined from DRC using Graph Pad Prism software (Ver. 5.04) (Graph Pad Software, Inc., USA) and Microsoft Excel 2007 (Microsoft Corporation, USA) application.

\section{Results and Discussion}

\subsection{UV-Visible Spectrophotometer Analysis}

The reduction of silver ions was easily monitored with color change and it is due to excitation of surface plasmon vibration of metal nanoparticles. The color of the reaction mixture started changing from light brown to dark brown, indicating the reduction of silver metal ions $\mathrm{Ag}^{+}$in to silver nanoparticles $\mathrm{Ag}^{0}$. Fig. 2 shows the UV-Visible spectra of synthesized silver nanoparticles. UV-visible spectroscopic studies revealed an appearance of surface plasmon resonance peak (SPR) at the 420 wavelength corresponds to silver nanoparticles formation.

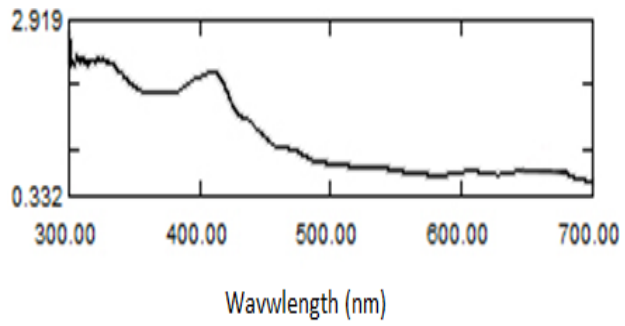

Fig. 2 UV-Visible spectra analysis of silver nanoparticles synthesized by Tinospora cordifolia root extract

https://doi.org/10.30799/jnst.211.19050112

\subsection{Fourier Transform Infrared Spectroscopy (FTIR)}

FTIR measurement was carried out to confirm the dual role of the plant extract as a reducing agent and capping agent. The FTIR spectrum of silver nanoparticle is shown in Fig. 3. The FTIR spectrum of silver nanoparticles showed distinct peaks $3261.63 \mathrm{~cm}^{-1}$, which assigned for $\mathrm{C}-\mathrm{H}$ stretching vibration of alkynes group, the peak at $2854.65 \mathrm{~cm}^{-1}$ indicating the presence of $\mathrm{C}$-H stretching mode in alkanes. The peak value at 2532.54 $\mathrm{cm}^{-1}$ corresponds to carboxylic acids and their derivatives. The peaks at $582.5 \mathrm{~cm}^{-1}$ and $603.72 \mathrm{~cm}^{-1}$ corresponds to $\mathrm{C}$ - $\mathrm{Br}$ stretch of alkyl halide. The absorption peak at $1404.18 \mathrm{~cm}^{-1}$ corresponds to $\mathrm{C}-\mathrm{O}$ stretching. The peak value at $1278.81 \mathrm{~cm}^{-1}$ corresponds to $\mathrm{C}-\mathrm{O}$ stretching of ester groups. The peak value at $1128.36 \mathrm{~cm}^{-1}$ and $1195.87 \mathrm{~cm}^{-1}$ corresponds to C-O stretching of alcohols and ethers. The absorption peaks at $898.83 \mathrm{~cm}^{-1}$ and $721.38 \mathrm{~cm}^{-1}$ corresponds to $\mathrm{C}-\mathrm{H}$ bend of alkenes.

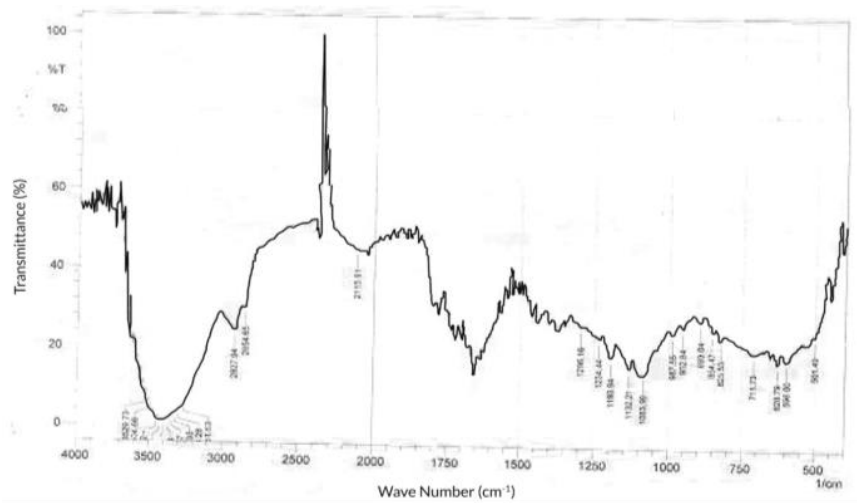

Fig. 3 FTIR spectra of silver nanoparticles synthesized by Tinospora cordifolia root extract

\subsection{SEM and TEM Analysis of Silver Nanoparticles}

Fig. 4 shows the SEM image for silver nanoparticles synthesized using methanol extract of Tinospora cordifolia root. SEM analysis was used to confirm the shape and morphology of the synthesized silver nanoparticles. It was confirmed that silver nanoparticles get aggregated into larger irregular structure. Morphology and size of the silver nanoparticles was investigated using transmission electron microscopy (TEM). TEM micrograph (Fig. 5) of silver nanoparticles shows that the majority of silver nanoparticles are spherical in shape with an average diameter of $100 \mathrm{~nm}$.

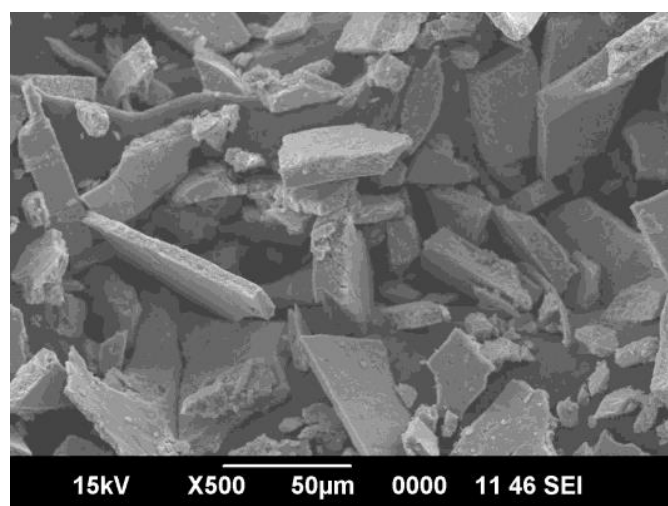

Fig. 4 scanning electron microscopic image of silver nanoparticles synthesized by Tinospora cordifolia root extract

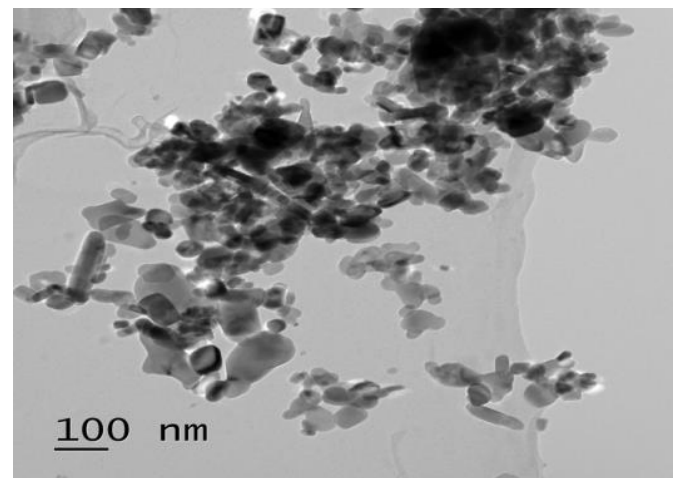

Fig. 5 TEM image of silver nanoparticles synthesized by Tinospora cordifolia root extract 


\subsection{X-Ray Diffraction Analysis (XRD)}

The crystalline nature of the synthesized silver nanoparticles from Tinospora cordifolia was confirmed by XRD analysis. As shown in Fig. 6 there are eight distinct reflections in the diffractogram at $27.88^{\circ}(111)$, $32.24^{\circ}(200), 38.22^{\circ}(211), 46.18^{\circ}(220), 54.87^{\circ}(311), 57.42^{\circ}(222)$ and $77.790(420)$. This confirmed face centered cubic structured silver nanoparticle formation. In addition to the Bragg peaks, additional peak were also observed at $64.50^{\circ}$. This is due to the organic compounds which are present in the extract and responsible for silver ions reduction and stabilization of resultant nanoparticles. This observation confirms the silver nanoparticles synthesized from root extract of Tinospora cordifolia was crystalline in nature. The XRD study had shown that the synthesized silver nanoparticles are having the average crystallite size around $21 \mathrm{~nm}$.

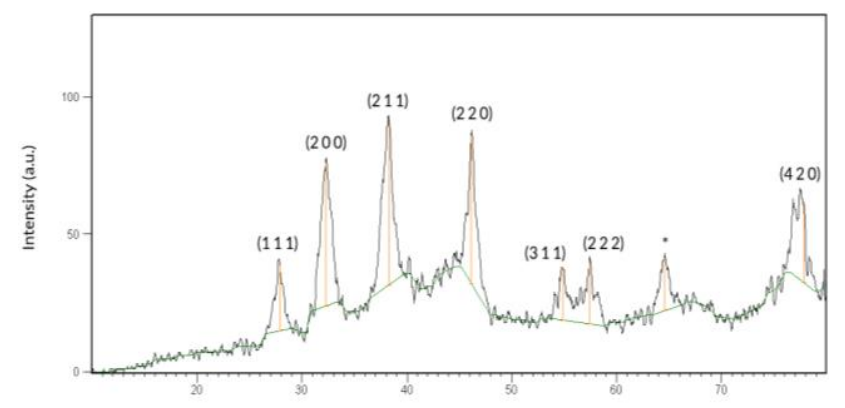

2 theta (degrees)

Fig. 6 XRD spectrum of silver nanoparticles synthesized by Tinospora cordifolia root extract

\subsection{Antibacterial Activity of Silver Nanoparticles}

Antibacterial activity of silver nanoparticle was evaluated against the following micro-organisms: Escherichia coli, Klebsiella pneumonia, Pseudomonas aeruginosa (Gram negative) and Staphylococcus aureus (Gram positive). Silver nanoparticles showed antibacterial activity against almost all the test organisms. The mechanism involved in antibacterial activity of silver nanoparticle is that it may attach to the surface of the cell membrane disturbing permeability, osmoregulation, electron transport and respiration. The Figs. 7-12 show the plot of log concentration vs \%cell inhibition of test compound against tested organisms.

Table 1 Percentage cell inhibition by synthesized silver nanoparticles from Tinospora cordifolia root extract test compounds against $E$. coli strain

\begin{tabular}{llll}
\hline $\begin{array}{l}\text { Conc. } \\
(\mu \mathrm{M} / \mathrm{mL})\end{array}$ & Log Conc. & \% Cell inhibition \\
\cline { 3 - 4 } 0.01 & -2.29 & Sample & STD \\
0.02 & -1.82 & 4.462 & 8.65 \\
0.05 & -1.34 & 13.62 & 14.38 \\
0.14 & -0.86 & 15.32 & 15.34 \\
0.41 & -0.39 & 27.862 & 16.87 \\
1.23 & 0.09 & 31.042 & 14.58 \\
3.70 & 0.57 & 36.57 & 36.04 \\
11.11 & 1.05 & 40.28 & 46.02 \\
33.33 & 1.52 & 41.32 & 57.26 \\
100.00 & 2.00 & 82.79 & 58.23 \\
$\mathrm{IC} 50 \mu \mathrm{L} / \mathrm{mL}$ & & 49.75 & 72.48 \\
$\mathrm{R}^{2}$ & & 0.8889 & 2.319 \\
\hline
\end{tabular}

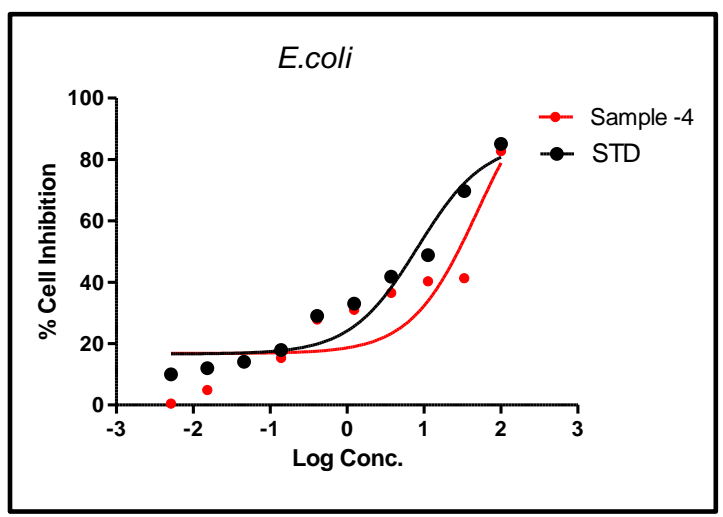

Fig. 7 Plot of log concentration vs \%cell inhibition of synthesized silver nanoparticles from Tinospora cordifolia root extracttagainst E.coli strain

https://doi.org/10.30799/jnst.211.19050112
Table 2 Percentage cell inhibition by synthesized silver nanoparticles from Tinospora cordifolia root extract against Staphylococcus aureus strain

\begin{tabular}{llll}
\hline $\begin{array}{l}\text { Conc. } \\
(\mu \mathrm{M} / \mathrm{mL})\end{array}$ & Log Conc. & \multicolumn{2}{l}{$\%$ Cell inhibition } \\
\cline { 3 - 4 } & & Sample & STD \\
\hline 0.01 & -2.29 & -0.321 & 12.56 \\
0.02 & -1.82 & 0.035 & 16.38 \\
0.05 & -1.34 & 0.458 & 17.82 \\
0.14 & -0.86 & 11.265 & 25.35 \\
0.41 & -0.39 & 14.895 & 32.61 \\
1.23 & $0.09-$ & 16.985 & 32.85 \\
3.70 & 0.57 & 21.38 & 34.68 \\
11.11 & 1.05 & 28.57 & 40.82 \\
33.33 & 1.52 & 48.05 & 51.34 \\
100.00 & 2.00 & 64.23 & 85.06 \\
$\mathrm{IC} 50 \mu \mathrm{L} / \mathrm{mL}$ & & 16.84 & 65.92 \\
$\mathrm{R}^{2}$ & & 0.9369 & 0.8990 \\
\hline
\end{tabular}

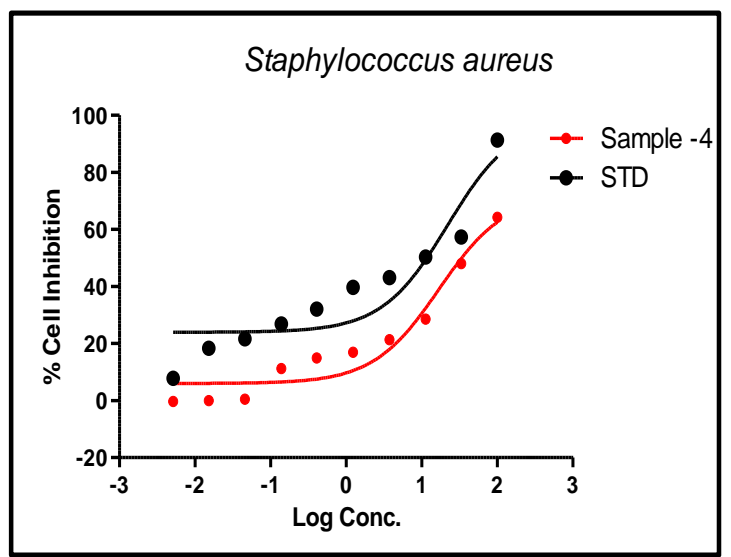

Fig. 8 Plot of log concentration vs \%cell inhibition of synthesized silver nanoparticles from Tinospora cordifolia root extract against Staphylococcus aureus strain

Table 3 Percentage cell inhibition by synthesized silver nanoparticles from Tinospora cordifolia root extract against Pseudomonas aeruginosa strain

\begin{tabular}{llll}
\hline \multirow{2}{*}{$\begin{array}{l}\text { Conc. } \\
(\mu \mathrm{M} / \mathrm{mL})\end{array}$} & Log Conc. & \multicolumn{2}{l}{ \% Cell inhibition } \\
\cline { 3 - 4 } & & Sample & STD \\
\hline 0.01 & -2.29 & 9.263 & 3.695 \\
0.02 & -1.82 & 11.472 & 8.231 \\
0.05 & -1.34 & 12.452 & 13.362 \\
0.14 & -0.86 & 24.321 & 18.972 \\
0.41 & -0.39 & 33.261 & 23.586 \\
1.23 & 0.09 & 45.321 & 31.875 \\
3.70 & 0.57 & 48.305 & 34.823 \\
11.11 & 1.05 & 54.782 & 40.985 \\
33.33 & 1.52 & 59.687 & 48.657 \\
100.00 & 2.00 & 75.638 & 82.64 \\
$\mathrm{IC} 50 \mu \mathrm{L} / \mathrm{mL}$ & & 6.740 & 26.99 \\
$\mathrm{R}^{2}$ & & 0.9403 & 0.8669 \\
\hline
\end{tabular}

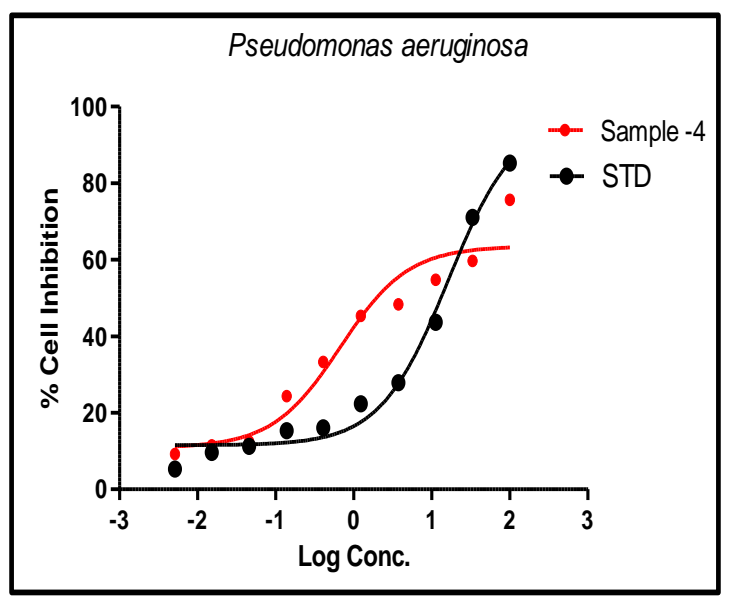

Fig. 9 Plot of log concentration vs \%cell inhibition of synthesized silver nanoparticles from Tinospora cordifolia root extract against Pseudomonas aeruginos as strain 
Table 4 Percentage cell inhibition by synthesized silver nanoparticles from Tinospora cordifolia Root Extract against K. Pneumoniaestrain

\begin{tabular}{llll}
\hline $\begin{array}{l}\text { Conc. } \\
(\mu \mathrm{L} / \mathrm{mL})\end{array}$ & Log Conc. & \multicolumn{2}{l}{ \% Cell inhibition } \\
\cline { 3 - 4 } & & Sample & STD \\
\hline 0.01 & -2.29 & -0.352 & 4.261 \\
0.02 & -1.82 & 6.896 & 7.032 \\
0.05 & -1.34 & 15.28 & 10.250 \\
0.14 & -0.86 & 26.752 & 16.203 \\
0.41 & -0.39 & 30.261 & 20.312 \\
1.23 & 0.09 & 36.012 & 27.362 \\
3.70 & 0.57 & 43.021 & 31.420 \\
11.11 & 1.05 & 50.026 & 37.281 \\
33.33 & 1.52 & 60.287 & 43.032 \\
100.00 & 2.00 & 84.021 & 84.325 \\
$\mathrm{IC} 50 \mu \mathrm{L} / \mathrm{mL}$ & & 2.935 & 67.42 \\
$\mathrm{R}^{2}$ & & 0.8602 & 0.8868 \\
\hline
\end{tabular}

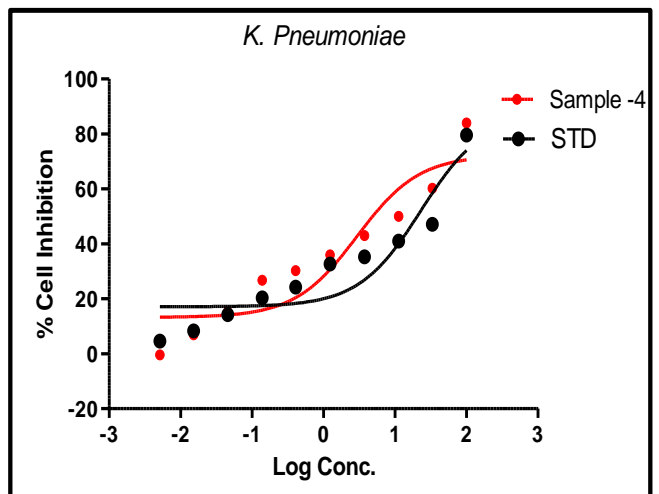

Fig. 10 Plot of $\log$ concentration vs \%cell inhibition of synthesized silver nanoparticles from Tinospora cordifolia root extract against K. Pneumoniae strain

\subsection{In-Vitro Cytotoxicity Analysis}

The in-vitro cytotoxicity effect of silver nanoparticles was studied against Hep-2 cell and MCF-7 cell line at different concentration 0.05, 0.15, $0.46,1.37 .4 .12,12.35,37.04,111.11,333.33$, and 1000 . The concentration required for $50 \%$ cell death (IC50) for MCF-7 and HEP-2 cell line were found to be 99.84 and 129.1 respectively. IC50 value was found to be less for the MCF-7 cell line than HEP-2 cell line.

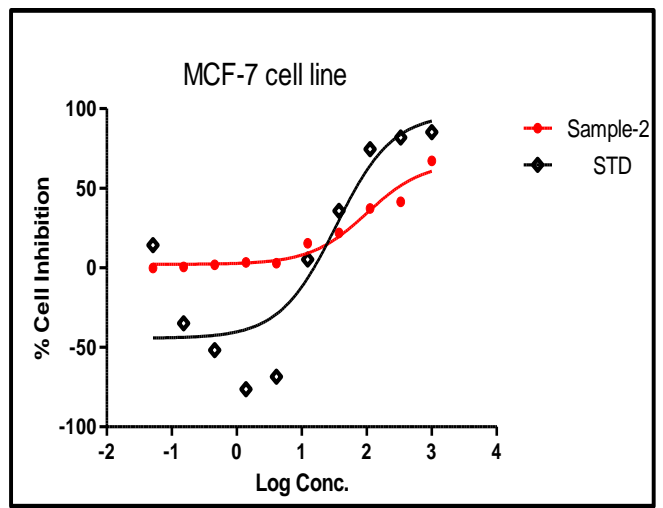

Fig. 11 Anticancer effect of synthesized silver nanoparticles from Tinospora cordifolia root extract on MCF-7 cell lines

Table 5 \%Cell inhibition of MCF-7 cells by synthesized silver nanoparticles from Tinospora cordifolia root extract at different concentration

\begin{tabular}{llll}
\hline $\begin{array}{l}\text { Conc. } \\
(\mu \mathrm{L} / \mathrm{mL})\end{array}$ & Log Conc. & \% Cell Inhibition \\
\cline { 2 - 4 } & -1.29 & -0.2351 & STD \\
\hline 0.05 & -0.82 & 0.5741 & 0.48 \\
0.15 & -0.34 & 1.8562 & 1.10 \\
0.46 & 0.14 & 3.2685 & 5.03 \\
1.37 & 0.61 & 2.8579 & 15.98 \\
4.12 & 1.09 & 15.3247 & 21.58 \\
12.35 & 1.57 & 21.8952 & 35.26 \\
37.04 & 2.05 & 37.2584 & 43.66 \\
111.11 & 2.52 & 41.3570 & 47.03 \\
333.33 & 3.00 & 67.2351 & 61.28 \\
1000 & & 99.84 & 82.57 \\
$\mathrm{IC}_{50}(\mu \mathrm{g} / \mathrm{mL})$ & & 0.9565 & 19.89 \\
$\mathrm{R}^{2}$ & & & 0.9191 \\
\hline https//doi.org/10.30799/jnst 211.19050112 &
\end{tabular}

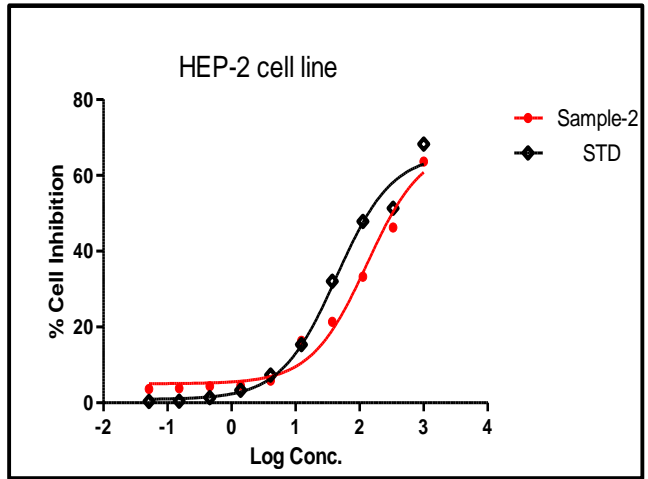

Fig. 12 Anticancer effect of synthesized silver nanoparticles from Tinospora cordifolia root extract on Hep-2 cell line

Table $6 \%$ Cell inhibition of HEP-2 cells by synthesized silver nanoparticles from Tinospora cordifolia root extract at different concentration

\begin{tabular}{llll}
\hline $\begin{array}{l}\text { Conc. } \\
(\mu \mathrm{L} / \mathrm{mL})\end{array}$ & Log Conc. & \multicolumn{2}{l}{ \% Cell Inhibition } \\
\cline { 3 - 4 } Sample & STD \\
\hline 0.05 & -1.29 & 3.6521 & 0.1542 \\
0.15 & -0.82 & 3.8574 & 0.0298 \\
0.46 & -0.34 & 4.3521 & 1.8523 \\
1.37 & 0.14 & 4.5784 & 3.8745 \\
4.12 & 0.61 & 5.8754 & 5.6523 \\
12.35 & 1.09 & 16.3520 & 10.8520 \\
37.04 & 1.57 & 21.3250 & 23.1620 \\
111.11 & 2.05 & 33.2640 & 35.6210 \\
333.33 & 2.52 & 46.2150 & 48.2650 \\
1000 & 3.00 & 63.5780 & 61.3254 \\
$\mathrm{IC}$ & & 129.1 & 83.06 \\
$\mathrm{R}^{2}$ & & 0.9820 & 0.9927 \\
\hline
\end{tabular}

\section{Conclusion}

The present study demonstrates biosynthesis of silver nanoparticles using root extract of Tinospora cordifolia as a potential reducing and stabilizing agent. Different biomolecules present in the plant extract facilitates the formation of silver nanoparticles. X-ray diffraction studies confirmed the formation of face centered cubic silver nanoparticles. TEM investigation results that the average size of synthesized silver nanoparticles is around $100 \mathrm{~nm}$. The obtained silver nanoparticles showed significant antibacterial and anticancer activity. This biological synthesis has several advantages like eco-friendly, low cost and non-toxic.

\section{Acknowledgement}

The authors are sincerely thankful to Sanjivani College of Pharmaceutical Education and Research (Shinganapur, Ahmednagar, India) and Sophisticated Instrumentation Centre, Kochi University (Kochi, India), for providing laboratory facilities and Instrumentation.

\section{References}

[1] S. Cheong, J.D. Watt, R.D. Tilley, Shape control of platinum and palladium nanoparticles for catalysis, Nanoscale 2 (2010) 2045-2053.

[2] Z. Li, X. Wang, G. Wen, S. Shuang, C. Dong, M.C. Paau, M.M.F. Choi, Application of hydrophobic palladium nanoparticles for the development of electrochemical glucose biosensor, Biosens. Bioelectron. 26 (2011) 46194623.

[3] B. Akta, F. Mikailov, L. Tagirov, Self-assembled FePt nanoparticle arrays as potential high-density recording media, magnetic nanostructures, Springer Series in Mater. Sci. 94 (2007) 15-28.

[4] A.G. Tkachenko, H. Xie, D. Coleman, W. Glomm, J. Ryan, et al., Multifunctional gold nanoparticle-peptide complexes for nuclear targeting, J. Am. Chem. Soc. 125 (2003) 4700-4701.

[5] P. Ghosh, G. Han, M. De, C.K. Kim, V.M. Rotello, Gold nanoparticles in delivery applications, Adv. Drug Delivery Rev. 60 (2008) 1307-1315.

[6] Ramesh Kumar Petla, S. Vivekanandhan, M. Misra, A.K. Mohanty, N. Satyanarayana, Soybean (glycine max) Leaf extract based green synthesis of palladium nanoparticles, J. Biomater. Nanobiotech. 3 (2012) 14-19.

[7] S. Ponarulselvam, C. Panneerselvam, K. Murugan, N. Aarthi, K. Kalimuthu, S. Thangamani, Synthesis of silver nanoparticles using leaves of Catharanthus roseus Linn. G. Don and their antiplasmodial activities, Asian Pacific J. Trop. Biomed. 2 (2012) 574-580.

[8] J. Huang, Q. Li, D. Sun Y. Lu, Y. Su, X. Yang, Biosynthesis of silver and gold nanoparticles by novel sundried Cinnamomum camphora leaf, Nanotechnol. 18 (2007) 105104-105114. 
[9] T. Klaus, R. Joerger, E. Olsson, C.G. Granqvist, Silver based crystalline nanoparticles, microbially fabricated, Proc. Nat. Acad. Sci. USA 96 (1999) 13611-13614.

[10] Y. Konishi, K. Ohno, N. Saitoh, Bioreductive deposition of platinum nanoparticles on the bacterium Shewanella algae, Jour. Biotechnol. 128 (2007) 648-653.

[11] B. Nair, T. Pradeep, Coalescence of nanoclusters and formation of submicron crystallites assisted by Lactobacillus, Crystal Growth Design. 2 (2002) 293298.

[12] I. Willner, R. Baron, B. Willner, Growing metal nanoparticles by enzymes, Adv. Mater. 18 (2006) 1109-1120

[13] S.S. Shankar, A. Rai, B. Ankamwar, A. Singh, A. Ahmad, M. Sastry, Biological synthesis of triangular gold nanoprisms, Nature Mater. 3 (2004) 482-488.

[14] D. Philip, C. Unni, S. Aromal, V.K. Vidhu, Murraya koenigii leaf-assisted rapid green synthesis of silver and gold nanoparticles, Spectrochim. Acta 78 (2011) 899-904.

[15] M. Mohammadlou, H. Maghsoudi, H. Jafarizadeh-Malmiri, A review on green silver nanoparticles based on plants: Synthesis, potential applications and ecofriendly approach, Int. Food Res. J. 23 (2016) 446-463.
[16] K.R. Kanude, Preeti Jain, Biosynthesis of CdS nanoparticles using Murraya koenigii leaf extract and their biological studies, Int. J. Sci. Res. Multidisc. Stud. 3 (2017) 5-10.

[17] M. Shanmugavadivu, S. Kuppusamy, Green synthesis of silver nanoparticles using Citrus reticulate fruit peels aqueous extract and their antibacterial activity, Int. J. Adv. Res. 5 (2017) 700-708.

[18] B. Kavya, N. Kavya V. Ramarao, G. Venkateshwarlu, Tinospora cordifolia (Willd) miers: nutritional, ethnomedical and therapeutic utility, Int. J. Res. Ayurveda Pharm. 6 (2015) 195-198.

[19] V. Rana, K. Thakur, R. Sood, V. Sharma, T.R. Sharma, Genetic diversity analysis of Tinospora cordifolia germplasm collected from northwestern Himalayan region of India, J. Genet. 91 (2012) 99-103.

[20] M. Parthipan, V. Aravindhan, A. Rajendran, Medico-botanical study of Yercaud hills in the eastern Ghats of Tamil Nadu, India, Anc. Sci. Life. 30 (2011) 104109.

[21] Soham Saha, Shyamasree Ghosh, Tinospora cordifolia: One plant, many roles, Ancient Sci. Life 31 (2012) 151-159.

[22] U. Spandana, Shaik Liakhat Ali, T. Nirmala, M. Santhi, S.D. Sipai Babu, A review on Tinospora cordifolia, Int. J. Current Pharm. Rev. Res. 4 (2013) 61-68. 